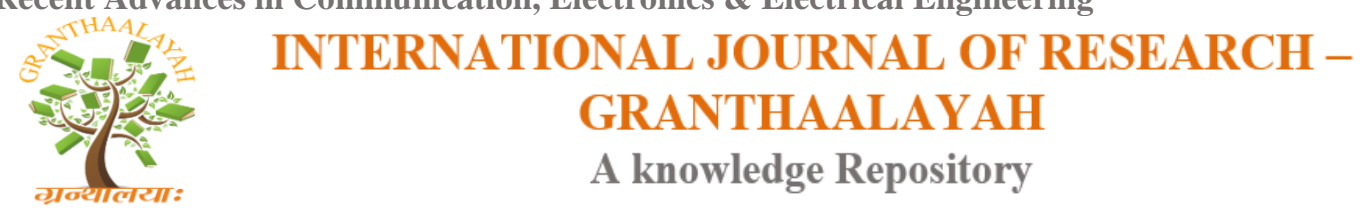

RACEEE - 17

\title{
MODELING OF STAND-ALONE SOLAR PHOTOVOLTAIC ENERGY CONVERSION SYSTEM
}

\author{
Nagendra K ${ }^{* 1}$, Supriya Anand ${ }^{2}$, Shubhanka C K ${ }^{3}$, Raghavendra Kumar ${ }^{4}$ \\ *1,2,3,4 Department of Electrical and Electronics Engineering, School of Engineering \\ and Technology, Jain University, Karnataka- 562112, India
}

DOI: https://doi.org/10.29121/granthaalayah.v5.i4RACEEE.2017.3331

\begin{abstract}
The conversion of light energy into electric energy is done by using photovoltaic system and photovoltaic cells are used as the basic element in energy conversion. This paper deals on the modeling and simulation of photovoltaic energy conversion system which is connected to a stand-alone system. The performance text is done on the system in order to determine the performance of the photovoltaic system under different circumstances is connected to a standalone system. The performance text is done on the system in order to determine the performance of the photovoltaic system under different circumstances. The output of the photovoltaic cells dependents on the radiation level that falls on the cells and temperature is the major aspect which affects the effects the efficiency of the PV system. So in this different irradiation levels are taken into account and the rise in temperature with respect to time graph is plotted and the voltage and current obtained for that particular irradiation are simulated and are plotted with respect to time. In this paper we use SIMULINK to conduct the simulation and performance test of photovoltaic system.
\end{abstract}

Keywords: Photovoltaic Cells (PV Cells); Stand-Alone System; IGBT Diode; Simulink; Irradiation.

Cite This Article: Nagendra K, Supriya Anand, Shubhanka C K, and Raghavendra Kumar. (2017). "MODELING OF STAND-ALONE SOLAR PHOTOVOLTAIC ENERGY CONVERSION SYSTEM." International Journal of Research - Granthaalayah, 5(4) RACEEE, 105-110. https://doi.org/10.29121/granthaalayah.v5.i4RACEEE.2017.3331.

\section{Introduction}

Due to the modernization of the world there is high demand for electrical energy whereas the amount of energy generation and the amount of energy requirement is not comparable. The demand for energy is more but the generation of energy has a slower pace in growth and due to the continuous usage of fossil fuel we are in a situation where there might be chance of 
Recent Advances in Communication, Electronics \& Electrical Engineering extinction of fossil fuels in the upcoming decades so there a need for switching the energy generation method from non-renewable to renewable energy sources. There are different form of renewable energy available in this nature. One such form is solar energy. The solar energy is an optimal source of energy which can be utilized for energy generation and its abundant in nature. Though the capital investment for the solar power plant is high but the output and the running cost is comparatively low than the other conventional methods. Though the availability of the energy source is high but the technology used to harvest it is not so efficient. But the main advantage of this solar energy system is that it can be harvested anywhere in the earth.

The solar-electrical conversion system mainly consists of solar photovoltaic cells. Photovoltaic cells are basically PN junction semiconductor diodes. The principle of solar PV cell can be explained on the basis of photoelectric effect which is defined as the emission of electrons from the conduction band due to the absorption of photon from a particular wavelength of sunlight falling on the PV panels. Different materials are used in manufacturing the PV cells. Mainly photovoltaic cells are available in two different forms:- mono crystalline silicon cells and polycrystalline silicon cells and they are connected in arrays so that it can be used for general purposes. The cells will be connected in parallel where there is a need for high current and in series where there is a need for high voltage. The objective of this paper is to conduct a performance test on the photovoltaic energy conversion system connected to a stand-alone system under different irradiation conditions and to verify its current and voltage graph with respect to time and to analyze the temperature rise with respect to time under different irradiation level. Stand-alone systems are used for smaller grids such as DC and AC electrical loads, household load etc.

\section{Modelling of Solar PV Cell}

The semiconductor theory gives us the I-V characteristics equation of the ideal PV cells. The equation are as follows:-

$I=I_{p v, \text { cell }}-\frac{I_{o, \text { cell }}\left[\exp \left(\frac{q V}{a k T}\right)-1\right]}{I_{d}}$
$I_{d}=I_{o, \text { cell }}\left\{\exp \left[\frac{q V}{A} * k * T\right]-1\right.$

Where,

Ipv,cell $=$ amount of current generated due the sunlight

Id = diode current

$\mathrm{I} 0$, cell $=$ reverse saturation of the diode or diode leakage current

$\mathrm{a}=$ Diode ideality constant

$\mathrm{q}=$ electron[1.60217646 x 10-19 C]

$\mathrm{k}=$ Boltzmann constant $\left[1.3806503 \times 10^{-23} \mathrm{~J} / \mathrm{K}\right]$

$\mathrm{T}=$ Temperature of the photovoltaic cells $[\mathrm{K}]$

The equation 1.1 hold good only for a single photovoltaic cells so additional parameters should be included in order to obtain the I-V characteristics of the complete photovoltaic array. 
Recent Advances in Communication, Electronics \& Electrical Engineering

$I=I_{p v}-I_{o}\left[\exp \left(\frac{V+R_{s} I}{V_{t} a}\right)-1\right]-\frac{V+R_{s} I}{R_{p}}$

Where,

Ipv $=$ Photovoltaic currents

Io = Saturation current

$\mathrm{Vt}=\mathrm{NskT} / \mathrm{q}=$ array thermal voltage

The current is increased by connecting cells in series and connected in parallel to increase the voltage. When the array is composed of Npp parallel connections then PV and saturation currents are expressed as:-

$\operatorname{Im}=$ IpvcellNpp

Io $=$ IocellNpp

And if the array is composed of Nss series connection of PV cell, then voltage is given by, $\mathrm{V}=\mathrm{Vt} \mathrm{t}^{*} \mathrm{Nss}$.

This equation originates the I-V curve as shown, where three remarkable points are highlighted: short circuit $(0, \mathrm{Isc})$, maximum power point (Vmp, Imp) and open-circuit (Voc, 0$)$.

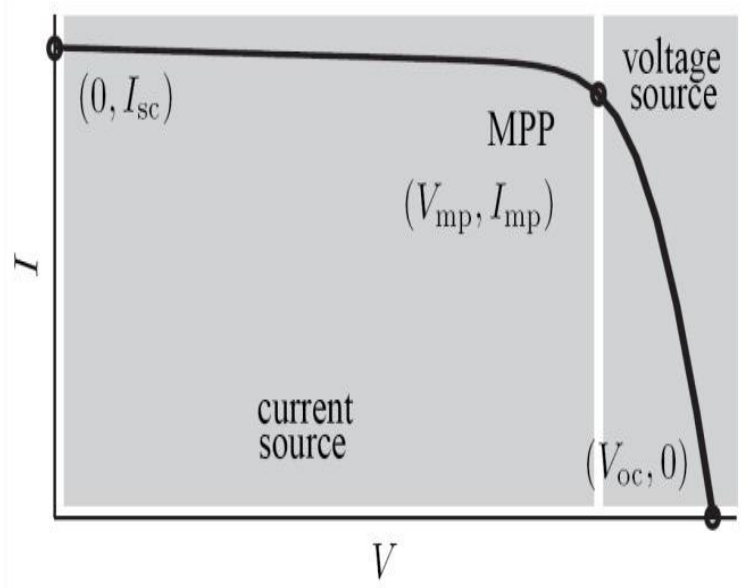

Figure 1: Characteristic I-V curve of a practical photovoltaic device and the three remarkable points: short circuit (0, Isc), maximum power point (Vmpp, Impp) and open-circuit (Voc,0).

Since the generated current depends linearly on the solar radiation, Isc $\approx \mathrm{Ipv}$ is assumed to be approximately equal. The temperature equation is given by:-

$\mathrm{I}_{\mathrm{pv}}=\left(\mathrm{I}_{\mathrm{pv}, \mathrm{n}}+\mathrm{K}_{\mathrm{I}} \Delta_{\mathrm{T}}\right) \frac{\mathrm{G}}{\mathrm{G}_{\mathrm{n}}}$

Where, Ipv,n [A] is the light-generated current at the nominal condition (at STP $250 \mathrm{C}$ and $1000 \mathrm{~W} / \mathrm{m} 2), \Delta \mathrm{T}=\mathrm{T}-\mathrm{Tn}$, where $\mathrm{T}$ is actual temperature and $\mathrm{Tn}$ is nominal temperatures in $\mathrm{K}$, $\mathrm{G}$ is the irradiation on the device surface in $\mathrm{W} / \mathrm{m} 2$, and $\mathrm{Gn}$ is the nominal irradiation in $\mathrm{W} / \mathrm{m} 2$ 
Recent Advances in Communication, Electronics \& Electrical Engineering

where, $\mathrm{Eg}$ is the band-gap energy of the semiconductor $(\mathrm{Eg} \approx 1.12 \mathrm{eV}$ for the polycrystalline $\mathrm{Si}$ at $250 \mathrm{C}$ ), and Io, $\mathrm{n}$ is the nominal saturation current:-

$$
\mathrm{I}_{\mathrm{o}, \mathrm{n}}=\frac{\mathrm{I}_{\mathrm{sc}, \mathrm{n}}}{\exp \left(\frac{\mathrm{V}_{\mathrm{oc}, \mathrm{n}}}{\mathrm{a} \mathrm{V}_{\mathrm{t}, \mathrm{n}}}\right)-1}
$$

The equation is modified to match the open circuit voltages and experimental data for a wide range of temperatures.

$I_{o}=\frac{I_{s c, n}+K_{I} \Delta_{T}}{\exp \left(\frac{\left(V_{o c, n}+K_{v} \Delta_{T}\right)}{a V_{t}}\right)-1}$

The diode saturation current Io and it temperature dependence is given by:-

$\mathrm{I}_{\mathrm{o}}=\mathrm{I}_{\mathrm{o}, \mathrm{n}}\left(\frac{\mathrm{T}_{\mathrm{n}}}{\mathrm{T}}\right)^{3} \exp \left[\frac{\mathrm{qE} \mathrm{g}}{\mathrm{ak}}\left(\frac{1}{\mathrm{~T}_{\mathrm{n}}}-\frac{1}{\mathrm{~T}}\right)\right]$

\section{Simulation of Stand Alone PV System}

The simulation is done under different irradiation level and temperature level of the photovoltaic cells. The mathematical models of the photovoltaic cells are implanted in the PV model system block in the simulation and the output from the PV model system is given to the boost converter where the variable output obtained from the PV model is regulated into a constant DC output. The diode will present the system from getting damaged due to the flow of reverse current from the load to the system in case of grid connected. The capacitor is used as a filter across the output to avoid the harmonics produced due to the switching operation in the boost converter.

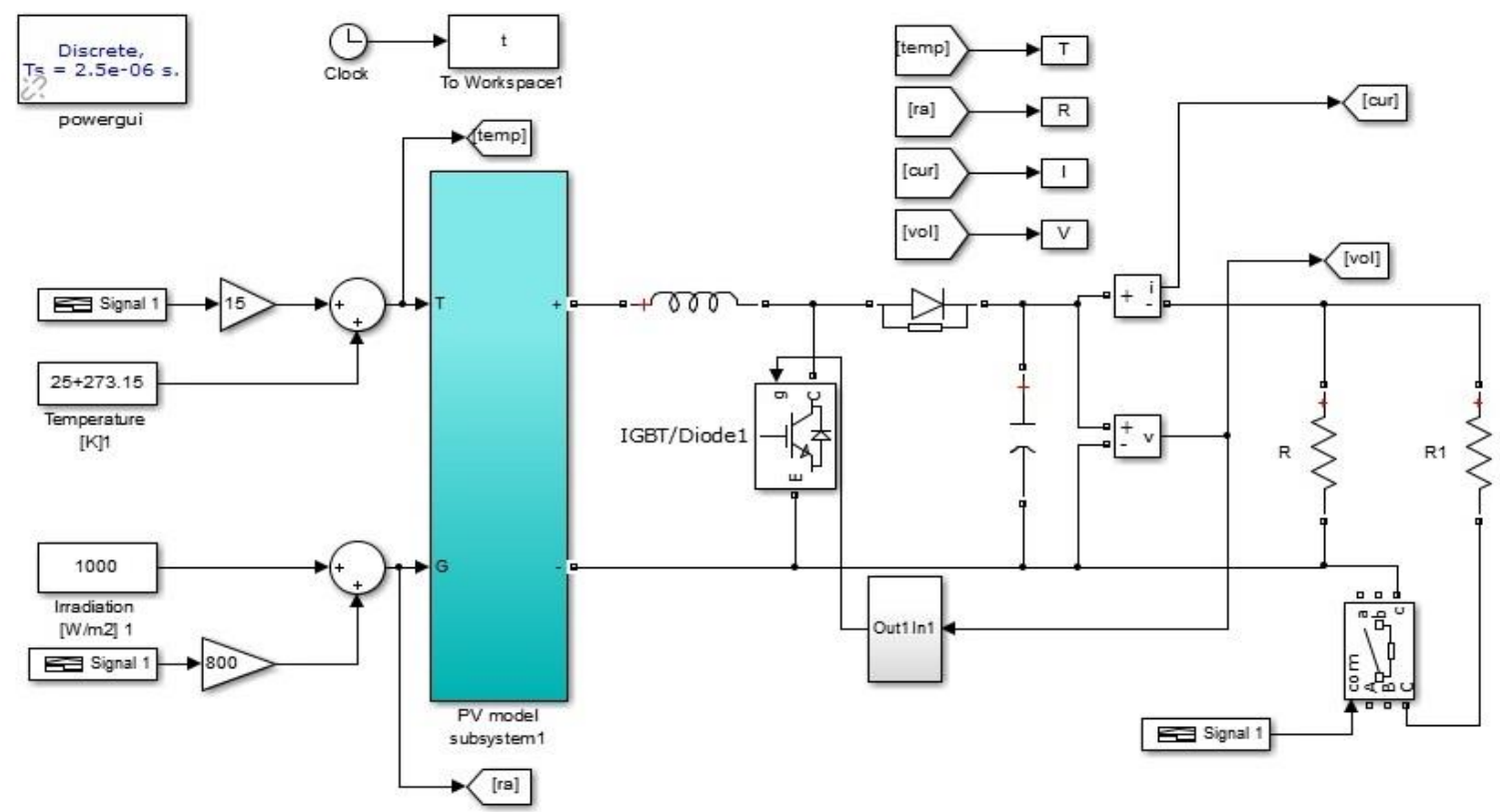

Figure 2: Simulation diagram of the PV system 
[Nagendra et. al., Vol.5 (Iss.4: RACEEE), April, 2017] ICV (Index Copernicus Value) 2015: 71.21
ISSN- 2350-0530(O), ISSN- 2394-3629(P) IF: 4.321 (CosmosImpactFactor), 2.532 (I2OR)

InfoBase Index IBI Factor 3.86

Recent Advances in Communication, Electronics \& Electrical Engineering

\section{Results}

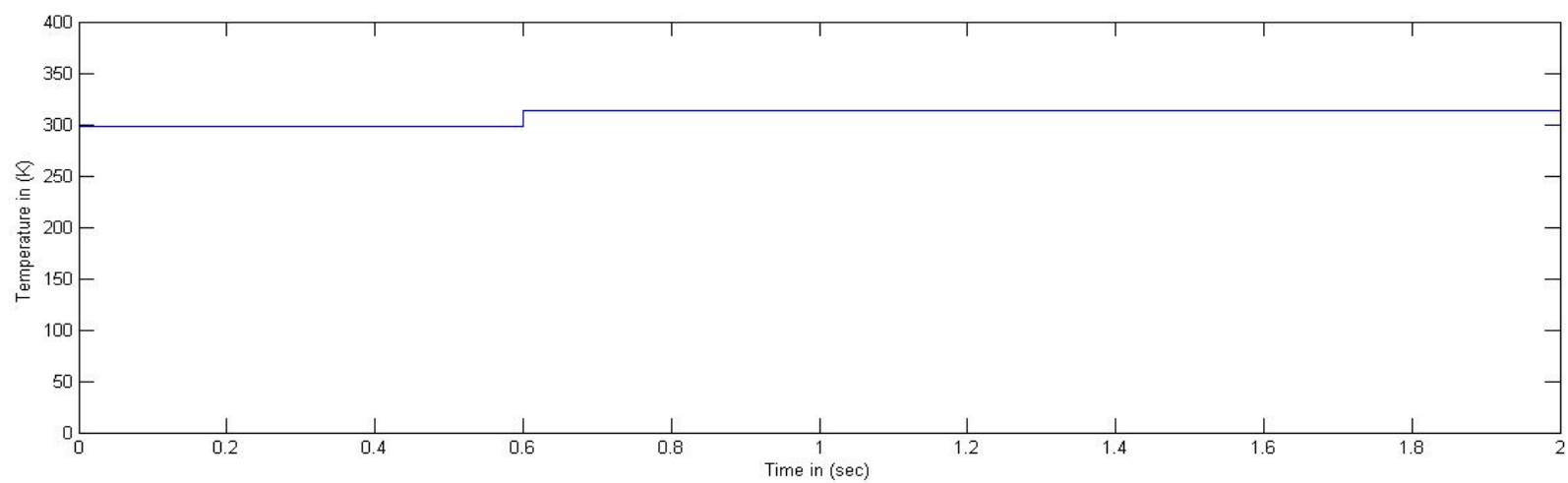

Figure 3: Temperature Variation

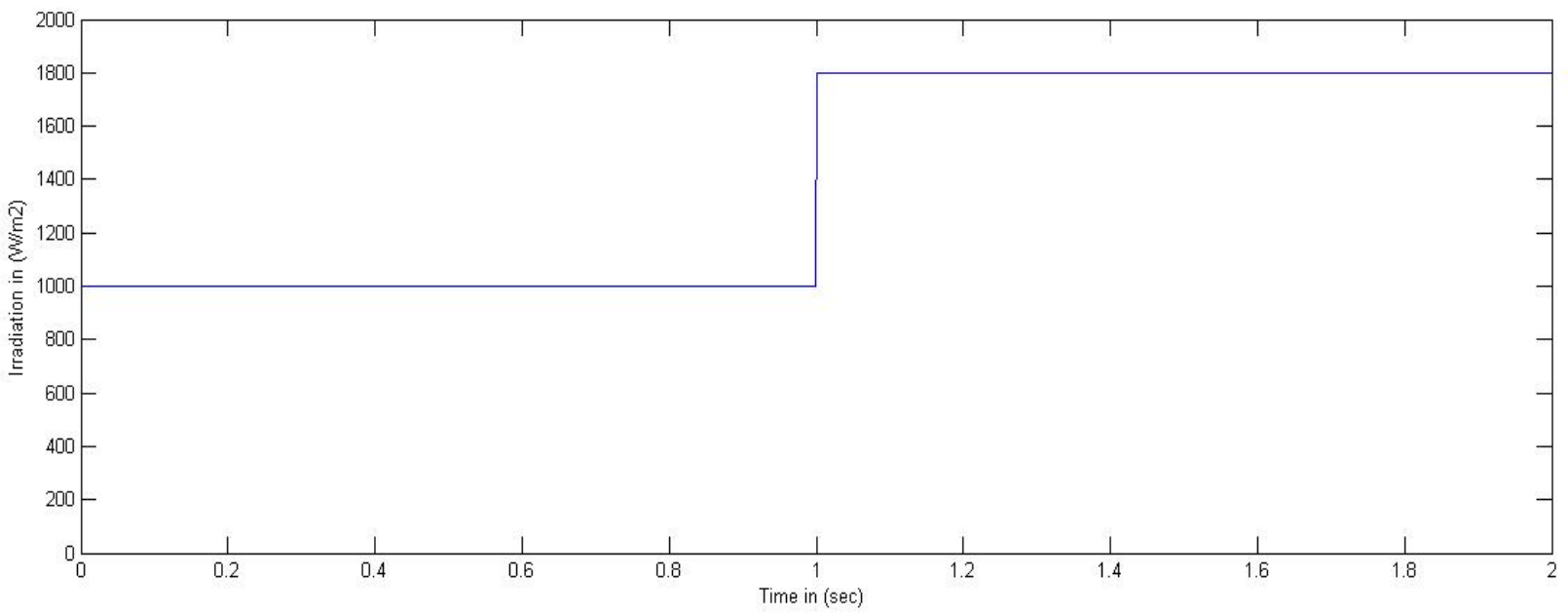

Figure 4: Change in Irradiation Level

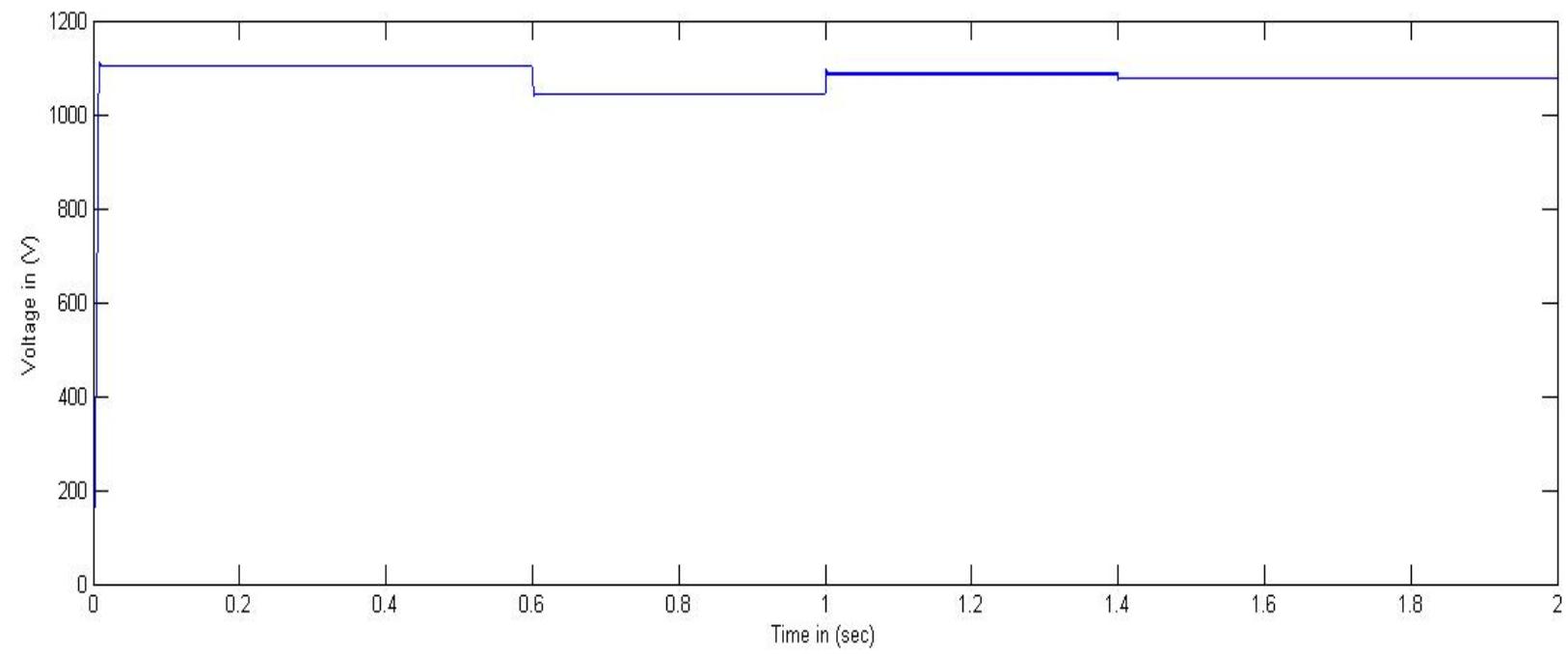

Figure 5: DC link voltage 
Recent Advances in Communication, Electronics \& Electrical Engineering

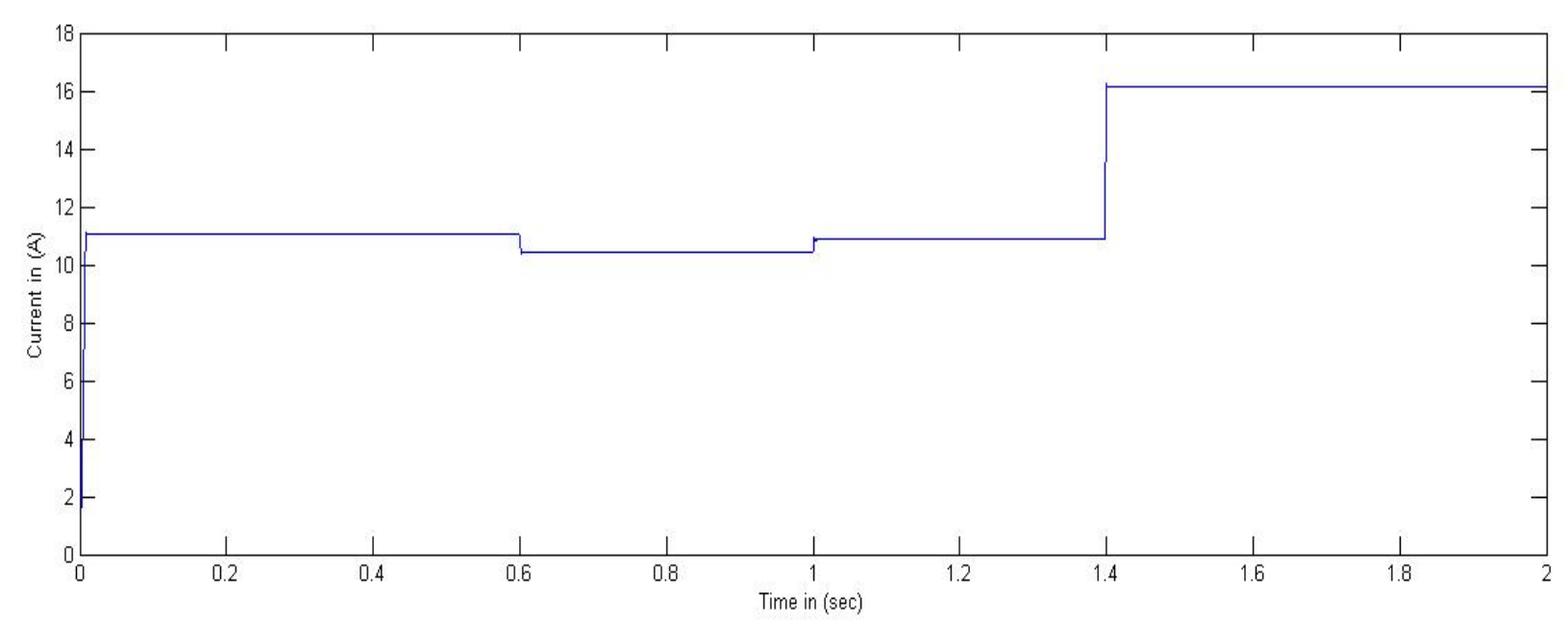

Figure 6: Current waveform

\section{Conclusion}

In this paper the modeling of the stand-alone solar photovoltaic system is done and the performance study of the system is carried out by simulating the system in the Simulink under various temperature and irradiation condition. The output obtained by the simulation is fed to the DC loads. By the performance test we can conclude that the irradiation of sun is directly and the temperature is inversely proportional to the output obtained.

\section{References}

[1] Akshay B. Zade, Asha Gaikwad, Ku. Prachi M. Jeevane, Ganesh Lohote.:Hybrid Solar and Wind Power Generation with Grid Interconnection System for Improving Power Quality.In: International Conference on Power Electronics, Intelligent Control and Energy Systems IEEE, 2016.

[2] SajibChakraborty, S M Salim Reza, WahidulHasan.:Design and Analysis of Hybrid Solar-Wind Energy System Using CUK \& SEPIC Converters for Grid Connected Inverter Application.In: IEEE PEDS, 2015.

[3] Md. Nurunnabi, N. K. Roy.:Grid Connected Hybrid Power System Design Using HOMER.In: 3rd International Conference on Advances in Electrical Engineering", December, IEEE, 2015.

[4] B. M Hasaneen and Adel A. ElbasetMohammed.:Design and Simulation of DC/DC Boost Converter.In: IEEE Power System Conference, 2008.

[5] MubasharYaqoobZargar, Mairaj-ud-Din Mufti, Shameem Ahmed Lone.: Modelling and Control of Wind Solar Hybrid System Using Energy Storage System.In: International Conference on Computing, Communication and Automation, IEEE, 2016.

*Corresponding author.

E-mail address: kbnagendra@gamil.com 